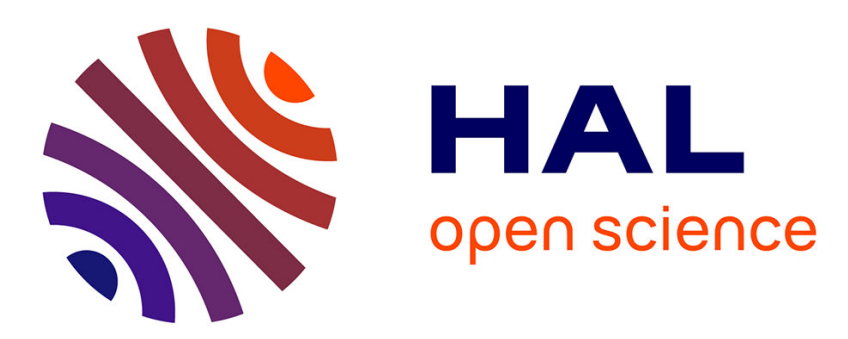

\title{
Morphological changes in brain and spinal cord tissues following low intensity laser irradiation
}

\author{
V. Stupak, S. Rabinovich, A. Burukhin
}

\section{To cite this version:}

V. Stupak, S. Rabinovich, A. Burukhin. Morphological changes in brain and spinal cord tissues following low intensity laser irradiation. Journal de Physique IV Proceedings, 1994, 04 (C4), pp.C4272-C4-272. 10.1051/jp4:1994465 . jpa-00252728

\section{HAL Id: jpa-00252728 https://hal.science/jpa-00252728}

Submitted on 1 Jan 1994

HAL is a multi-disciplinary open access archive for the deposit and dissemination of scientific research documents, whether they are published or not. The documents may come from teaching and research institutions in France or abroad, or from public or private research centers.
L'archive ouverte pluridisciplinaire HAL, est destinée au dépôt et à la diffusion de documents scientifiques de niveau recherche, publiés ou non, émanant des établissements d'enseignement et de recherche français ou étrangers, des laboratoires publics ou privés. 


\title{
Morphological changes in brain and spinal cord tissues following low intensity laser irradiation
}

\author{
V.V. STUPAK, S.S. RABINOVICH and A.A. BURUKHIN
}

Research Institute of Traumatology and Orthopaedics, Frunze Str. 17, Novosibirsk 91, 630091, Russia

The influence of laser emission on opened infact brain and spinal cord was studied in two series of 92 animals.

Semiconductor laser $(I=830 \mathrm{~nm})$ was used in series $I$ and He-Ne laser $(I=630)$ in series II. output power of each laser was $4 \mathrm{mVt}$. Exposure time was $3.5,15$ and 30 minutes in each series of experiment. Cerebral tissue was examined during acute period in 24 hours, 5 and 15 days after the radiation by means of conventional hystological viewing technique.

The most pronounced morphological changes in the brain and the spinal cord were revealed in 24 hours after radiation by semiconductor laser with the exposure time being 30 minutes. The most swere damages take place in subcortical layer of the brain and in pyramidal cells of posterior horns of the spinal cord. These changes may be classified as pyknosis and kariorrhexis of olial cells. The manifestation of edema to the extent of kiribrosis changes in the white matter catches the eve. The cerebral cortex suffers the least.

At 5 days examination the changes in pyramidal cells of the spinal cord and glial cells of the brain appear less severe. The edema of cerebral tissue is still noticeable.

At 15 days examination the structure of nerve cells is changed not significantly. The edema of the white matter is less pronounced.

The examination of cerebral specimens in acute period and in 24 hours after He-Ne laser radiation reveals significantly less morphological changes as compared with previous series. Minimal damages of the cortex and the white matter of the brain and posterior horn neurons of the spinal cord manifest themselves in irraqular granulation of cortex neurons with minimal tigrolysis in isolated cells. The edema of the white matter of the brain and the dorsal columns of the spinal cord is uncomparably less manif estated.

At 5 days cortex cells of the brain and pyramidal cells of posterior columns of the spinal cord appear infact. Signs of periceliular edema are pracfically absent.

At 15 days the hystological picture is normalized.

Thus, the experimental comparison studies of two types of lasers have revealed the principal difference of their influence in the structure of nerve cells. Subcortical layer of brain glial tissue and pyramidal cells of the posterior spinal columns are the most damagable by the semiconductor laser emission. Yet these changes regress rapidly and at 15 days only the signs of regressing edema of the cerebral matters, and very light dystrophic changes in neurons in regressive phase are preserved. The most infact structure of cellular and extracellular elements of white and grey matter is preserved in case of the exposure to He-Ne laser. The changes are practically not detectable at 5 days of the experiment and at 15 days the cerebral tissue appears intact. 